\title{
TESTING BHANDARI Z-SCORE MODEL BANKRUPTCY PREDICTION USING CASH FLOW
}

\author{
Ely Kartikaningdyah, SE., M. Si ${ }^{1)}$, Barcha Handal Sakti ${ }^{2}$ \\ Managerial Accounting Department, Politeknik Negeri Batam \\ Jl. Ahmad Yani, Batam Centre, Batam 29461, Indonesia \\ 1)E-mail: ely@polibatam.ac.id \\ ${ }^{2)}$ E-mail: tata.poltek@webmail.com
}

\begin{abstract}
This research aimed to know whether the predictor variables on Bhandari's z-score model having discriminating power which in each of the group has significant difference. Sample which was being used to assist was the manufacture company that consisted of healthy company and the unhealthy company enrolled in Indonesia stock exchange in the period of 2012-2014. Sample collecting method used purposive sampling and cross section was the data used in this research. This research was conducted by using Multivariate Discriminant Analysis (MDA). The result of this study showed predictor variable that gave discriminating power which stood of quality of earning (EAQ), operating cash flow divided by current liabilities (OCFCL), operating cash flow margin (OCFM), and operating cash flow return on total assets (OCFA) in distinguishing the healthy and unhealthy company significantly.
\end{abstract}

Keywords: Bhandari's z-score model, cash flow, bankruptcy prediction, discriminating power. 


\section{Introduction}

One interesting study in finance and accounting is the prediction of bankruptcy of the enterprise. Continuity of operations of an enterprise in the future become a very important thing that a correct prediction is needed. Therefore, the analysis and bankruptcy prediction model of a company is very important for the various parties as stakeholders, investors, government, management and accounting.

Altman model famous Z-score is the result of the score obtained from the standard calculation times of financial ratio-ratio that reflects the company's possible bankruptcy. Most of the models empirical research using data derived from the income statement and balance sheet. however, very few have studied bankruptcy using data from the company's cash flow statement or using a ratio based on information from the cash flow statement.

Based on research Bhandari and Iyer (2013) conducted in the United States aims to build a new model in predicting business failure, by using the measurement basis most of the cash flow statement is as predictor variables and using discriminant analysis techniques. Previous research has a unique in many ways. First, the sample used is not specified a specific industry. Samples were taken from COMPUSTAT more than 20 two-digit SIC code differences, which means that the model is very generic researchers. The sample consisted of 50 "filed" firms and 50 non-filed firms. Second, seven predictor variables selected logically. Third, most of the predictor variables using information from the operating cash flow of the cash flow statement. Fourth, all the bankrupt company using the latest sample period 2008-2010.

This study aims to prove the predictor variables in the Bhandari's z-score model have Discriminating power that each group has a significant difference. This research differs from research Bhandari and Iyer (2013) that is this study used a sample selection of grey area or unhealthy company (represented by companies experiencing financial distress) and healthy company.

\section{Theory and Development Hypothesis}

\subsection{Agency Theory}

Hidayat and Meiranto (2014) stated that agency theory is a reflection of the relationship between the principal as an investor or shareholder of the company and the agent as part of the management. However, because the principal does not have enough information about the performance agent, so that the principal does not know how the actual performance of agents in contributing to the company.

Suwardjono (2014) stated that in the agency theory tends agent will act for the benefit of a private company but agents are always trying to fulfill the contract. The conflict between principal and agent in a company can be generated from the excess cash flow. However, the excess cash flow tends to be invested in things that are not related to the main activity of the company. Therefore, it will cause the difference in interest between principal and agent as if investors prefer investments with high risk while management preferring lower risk in investing.

Thus, the principal should be able to consider the viability of the company, if there is no alignment purpose between principal and agent then it could impact on the company as well even towards bankruptcy of the company.

\subsection{Model Z-score Prediction Company Bankruptcy} Harahap (2015) stated prediction models can be used for field analysis of the company's financial statements, because one of the purposes of the statement of cash flows are forecast on the company's financial condition in the future.

Harahap (2015) stated that net cash flow prediction models can be used by companies to determine how much the company's net cash inflows next year, so that will showed about the company future financial condition.

\subsection{Cash Flow Statement}

Harahap (2015) stated analysis of cash flow is in line with the preparation of the cash flows statement. The 
amount of relevant information assessed from cash flow statements regarding the company's ability to get a profit and liquidity of companies in the future. Bhandari and Iyer (2013) stated that the most important of the cash flows statement is operating activities.

\subsection{Hypothesis Development}

Sharma (2001) stated that it is basically cash flow is not a new concept. In a previous study of the company's bankruptcy prediction can be concluded that the relationship between cash flow and debt repayments are linked to financial distress it is reasonable because it is associated is sourced from the company's cash flow.

Eliu (2014) stated increasing size and activity of the company long-term, is expected to increase sales so the impact on the company's sales growth to increase in retained earnings which will be received by the company. Suwardjono (2014) suggested that the retained earnings derived from the company's operations were reduced by dividends. Increasing the amount of retained earnings, is expected to reduce the use of debt, so the possibility that the company's financial distress is getting smaller.

If the financing company uses more debt, the risk is that the company is a future payment difficulty due to debts greater than assets. Based on the above it hypothesis in this study are as follows:

H1: the predictor variables on Bhandari's z-score model having discriminating power which in each of the group has significant difference.

\begin{tabular}{|l|l|}
\hline \multicolumn{2}{|c|}{ Independent Variable } \\
\hline $\begin{array}{l}\text { Operating cash flow divided by current liabilities } \\
\text { Cash flow coverage of interest } \\
\text { Operating cash flow margin } \\
\text { Operating cash flow return on total assets } \\
\text { Quality of earning } \\
\text { Quick ratio } \\
\text { Sales growth }\end{array}$ \\
\hline
\end{tabular}

Picture 1 Research Model

\section{Research Methods}

Method used in this study is a quantitative approach, because in this study the source of the data used comes from secondary data that is financial statements of companies listed in Indonesia Stock Exchange 2012-2014.

In this research data analysis tools used SPSS 22. This research was conducted by using discriminant analysis as the statistical techniques in data processing, discriminant analysis selected for the dependent variables used in this study is the categorical variables and the independent variable is multivariate normal distribution so matches using discriminant analysis.

\subsection{Population and Sample}

The object of research used in this research is manufacturing companies listed in Indonesia Stock Exchange. The sample used in this study using purposive sampling method includes manufacturing companies listed in Indonesia Stock Exchange 20122014.

Criteria for selection of the sample to be studied is as follows:

a. Manufacturing companies listed in Indonesia Stock Exchange 2012-2014 period consisting of the company's financial distress or unhealthy represented by companies whose negative net profit and healthy company is represented by companies whose positive net profit.

b. The financial statements of the company using the rupiah currency.

Table 1

Sampling Results

\begin{tabular}{|c|c|c|c|c|}
\hline \multirow{2}{*}{ Description Data } & \multicolumn{3}{|c|}{ Observation year } & \multirow{2}{*}{ Total } \\
\hline & 2012 & 2013 & 2014 & \\
\hline $\begin{array}{l}\text { Manufacturing companies } \\
\text { listed in Indonesia Stock } \\
\text { Exchange }\end{array}$ & 137 & 141 & 147 & 425 \\
\hline Firms not using rupiah & $(27)$ & $(28)$ & (29) & (84) \\
\hline $\begin{array}{l}\text { The Company does not } \\
\text { publish financial statements }\end{array}$ & $(1)$ & $(0)$ & (6) & (7) \\
\hline Delisting company & (3) & (2) & (1) & (6) \\
\hline $\begin{array}{l}\text { Company financial reports } \\
\text { incomplete }\end{array}$ & (10) & $(15)$ & $(28)$ & $(53)$ \\
\hline Total Sample Company & 96 & 96 & 83 & 275 \\
\hline
\end{tabular}

Source: Data processed 
3.2 Variable and Measurement Research

Dependent variables

The dependent variable in this study is discriminating power that will show predictor variables in the Bhandari's z-score model which has the ability or the power to distinguish the two groups of companies, that is healthy and unhealthy companies in the manufacturing companies in the Indonesia Stock Exchange.

Independent variables

a. Operating Cash Flow Divided by Current Liabilities This ratio measures the company's ability to pay shortterm obligations. The formula for calculating OCFCL (Bhandari and Iyer, 2013) are:

Operating cash flow divided by current liabilities = Operating cash flow Current liabilities

b. Cash Flow Coverage of Interest

Bhandari and Iyer (2013) stated this ratio can measure the ability of companies in the payment of debt interest obligations. The formula for calculating CFCI (Bhandari and Iyer, 2013) are:

Cash flow coverage of interest $=$ Operating cash flow+ Interest + Tax Interest

c. Operating Cash Flow Margin

This ratio describes the company's ability to get profits through all of the capabilities and resources that exist in the company. The formula for calculating OCFM (Bhandari and Iyer, 2013) are:

Operating cash flow margin = Operating cash flow

Net sales

d. Operating Cash Flow Return on Total Assets This ratio is almost same as the return on assets (ROA) but instead of using net income instead of cash flow from operations. This ratio describes the asset turnover as measured from the company's operating cash flows. The formula for calculating the OCFA (Bhandari and Iyer, 2013) are:

Operating cash flow return on total assets = Operating cash flow

$$
\text { Total assets }
$$

e. Quality of Earnings

This ratio shows the company's ability to get profits as measured by the amount of earnings before deducting interest and taxes compared to cash flow from operating activities of the company. The formula for calculating the QE (Bhandari and Iyer, 2013) are:

Quality of earning = Earning Before Interest and Tax

Operating cash flow

\section{f. Quick Ratio}

Harahap (2015) suggests this ratio indicates the ability of the most liquid assets are able to cover current debts. The formula for calculating the QR (Bhandari and Iyer, 2013) are:

Quick Ratio $=$ Current Assets - Inventories

Current Liabilities

\section{g. Sales Growth}

Gunawan et al. (2014) stated the company's growth may reflect the company's good performance for external parties, so that in the future the company will grow and develop into a great company. The formula for calculating SG (Bhandari and Iyer, 2013) are:

3 Year Sales Growth $=\sqrt[n]{\left(\frac{\text { Net Sales } t}{\text { Net Sales } t-(n-1}\right)}-1$

\section{Results and Discussion}

\subsection{Normality Test}

Normality test used to determine whether residual values studied normal distribution or not. In Table 2 indicates that data are normally distributed.

Table 2

Kolmogorov smirnov Test Result

\begin{tabular}{ll}
\hline Kolmogorov-Smirnov Z & $\begin{array}{c}\text { Unstandardized } \\
\text { Residual }\end{array}$ \\
\hline Asymp. Sig. (2-tailed) & 0,217 \\
\hline
\end{tabular}

Source: Data processed

\subsection{Multicollinearity Test}

Multicollinearity test was used to determine whether or not the relationship between independent variables and the value of each independent variable on the variables associated. In Table 3 shows that there is no multicollinearity on each variable with the results VIF $<10.00$ and Tolerance values $>0.10$. 
Table 3

Multikolinearitas Test Result

\begin{tabular}{lccc}
\hline \multicolumn{1}{c}{ Variable } & Tolerance & VIF \\
\cline { 1 - 1 } OCFCL & 0,441 & & 2,269 \\
CFCI & 0,583 & 1,716 \\
OCFM & 0,865 & 1,156 \\
OCFA & 0,723 & 1,383 \\
EAQ & 0,844 & 1,185 \\
QR & 0,773 & 1,294 \\
SG & 0,948 & 1,055 \\
\hline
\end{tabular}

Source: Data processed

\subsection{Heterokedastisitas Test}

Heterokedastisitas test aimed to determine whether there is inequality of the variance from the one residuals observations or others. In Table 4 shows that there is no heterokedastisitas on each variable with the results $\mathrm{sig}>0.05$.

\section{Table 4}

\begin{tabular}{lc}
\multicolumn{3}{c}{ Heterokedastisitas } & Test Result \\
\hline \multicolumn{1}{c}{ Variable } & Sig. \\
\hline OCFCL & 0,622 \\
CFCI & 0,243 \\
OCFM & 0,297 \\
OCFA & 0,064 \\
EAQ & 0,172 \\
QR & 0,734 \\
SG & 0,740 \\
\hline \multicolumn{2}{l}{ Source: Data processed }
\end{tabular}

\subsection{Hypothesis Test Results}

Researcher using stepwise method that is automatically by discriminant analysis will start by selecting the independent variables that have the best ability to discriminate and show the predictor variables which are the most efficient in distinguishing companies unhealthy or healthy. The results of hypothesis testing performed by multivariate discriminant analysis (MDA) can seen in table 5.

Table 5

\begin{tabular}{clcc}
\multicolumn{4}{c}{ Variables Entered/Removed $^{\mathbf{a}, \mathbf{b}, \mathbf{c}, \mathbf{d}}$} \\
\cline { 4 - 4 } Step & \multirow{2}{*}{ Variable } & \multicolumn{2}{c}{ Exact F } \\
\cline { 3 - 4 } & & Statistic & Sig. \\
\hline 1 & EAQ & 35,822 & 0,000 \\
3 & OCFCL & 38,257 & 0,000 \\
4 & OCFM & 34,293 & 0,000 \\
& OCFA & 28,259 & 0,000 \\
\hline
\end{tabular}

Source: Data processed

Seen from seven variables in the Bhandari's z-score model there are only four variables that have discriminating power the largest to include in the discriminant function, that is the variable quality of earnings (EAQ), operating cash flow divided by current liabilities (OCFCL), operating cash flow margin (OCFM), and operating cash flow return on total assets (OCFA), while the variable cash flow coverage of interest (CFCI), quick ratio (QR) and sales growth (SG) is not included in the discriminant function.

The variables that have a high $F$ value and significance value $<0.05$ is entered, the variable quality of earnings (EAQ) with $\mathrm{F}$ value of 35.822, variable operating cash flow divided by current liabilities (OCFCL) with $F$ value of 38.257 , variable operating cash flow margin (OCFM) with $\mathrm{F}$ value of 34.293 , and variable operating cash flow return on total assets (OCFA) with $\mathrm{F}$ value of 28.259. This means that the variable quality of earnings (EAQ), operating cash flow divided by current liabilities (OCFCL), operating cash flow margin (OCFM), and operating cash flow return on total assets (OCFA) significantly affects unhealthy or health of a company. Therefore, the purpose of this study want to determine which variables are the most efficient in distinguishing companies that are unhealthy or healthy then used stepwise procedure. Mahalonobis distance will be used to determine which variable has discriminating power. In this case the minimum value of 0.05 is used as a condition to enter variables and Mahalanobis distance is used to select the variables (Ghozali, 2012).

Table 6

\begin{tabular}{|c|c|c|}
\hline \multicolumn{3}{|c|}{ Variables in the Analysis } \\
\hline Step & Variable & Sig. of F to Remove \\
\hline 1 & EAQ & 0,000 \\
\hline \multirow[b]{2}{*}{2} & EAQ & 0,000 \\
\hline & OCFCL & 0,000 \\
\hline \multirow{3}{*}{3} & EAQ & 0,000 \\
\hline & OCFCL & 0,000 \\
\hline & OCFM & 0,000 \\
\hline \multirow{4}{*}{4} & EAQ & 0,000 \\
\hline & OCFCL & 0,000 \\
\hline & OCFM & 0,000 \\
\hline & OCFA & 0,006 \\
\hline
\end{tabular}

Source: Data processed

Table 6 shows the sequence condition of the independent variables analyzed. Stages of the variable input is determined by the size of the numbers Sig. of F to Remove, where a smaller number be ahead. The above data shows the maximum value of Mahalanobis distance in the variable quality of earnings (EAQ) 
which has a significance of 0.000 so that the variable quality of earnings (EAQ) be the first.

This means that quality of earnings (EAQ) significantly more than the operating cash flow divided by current liabilities (OCFCL), operating cash flow margin (OCFM), and operating cash flow return on total assets (OCFA) to distinguish the unhealthy or healthy company.

Sarwono (2015) stated that to test whether the predictor variables in each group has a significant difference or not, we will do a test of hypothesis as below shown in Table 7:

Table 7

\begin{tabular}{|c|c|c|}
\hline \multicolumn{3}{|c|}{ Wilks' Lambda } \\
\hline $\begin{array}{c}\text { Number of } \\
\text { Variable }\end{array}$ & Lambda & Sig. \\
\hline 1 & 0,884 & 0,000 \\
\hline 2 & 0,780 & 0,000 \\
\hline 3 & 0,725 & 0,000 \\
\hline 4 & 0,705 & 0,000 \\
\hline
\end{tabular}

Based on the significant of the numbers in table 7 shows that the four predictor variables is smaller than $0.05(0.000<0.05)$, the fourth means predictor variables in each group is really significant. This study shows the predictor variables which have discriminating power in predicting the company is unhealthy or healthy Bhandari's z-score model, thus supporting the hypothesis 1 proposed by the researcher that the predictor variables in the Bhandari's z-score model having discriminating power that each group has significant different.

The possibility of errors in predicting the Bhandari's $\mathrm{z}$-score model, are presented in Table 8 as follows:

Table 8

Classification Results

\begin{tabular}{|c|c|c|c|c|}
\hline \multirow{2}{*}{\multicolumn{2}{|c|}{ Firm Condition }} & \multicolumn{2}{|c|}{ Predicted Group Membership } & \multirow{2}{*}{ Total } \\
\hline & & Unhealthy & Healthy & \\
\hline & Unhealthy & 33 & 3 & 36 \\
\hline Count & Healthy & 35 & 204 & 239 \\
\hline \multirow{2}{*}{$\%$} & Unhealthy & $91,70 \%$ & $8,30 \%$ & $100 \%$ \\
\hline & Healthy & $14,60 \%$ & $85,40 \%$ & $100 \%$ \\
\hline
\end{tabular}

a. $86,20 \%$ of original grouped cases correctly classified.

Source: Data processed

Table 8 shows that the accuracy rate is $86.20 \%$ [(91.70+85.40\%)/2] of 275 companies that have been classified correctly in the same group with the data originally. Based on calculations performed using Excel, the obtained results of the company's bankruptcy prediction shown in Table 9 below.

Table 9

Bankruptcy Prediction Results

\begin{tabular}{|c|c|c|c|c|}
\hline \multirow{2}{*}{\multicolumn{2}{|c|}{ Firm Condition }} & \multicolumn{2}{|c|}{ Predicted Group Membership } & \multirow[b]{2}{*}{ Total } \\
\hline & & Unhealthy & Healthy & \\
\hline \multirow[b]{2}{*}{ Count } & Unhealthy & 34 & 2 & 36 \\
\hline & Healthy & 58 & 181 & 239 \\
\hline \multirow{2}{*}{$\%$} & Unhealthy & $94,44 \%$ & $5,56 \%$ & $100 \%$ \\
\hline & Healthy & $24,27 \%$ & $75,73 \%$ & $100 \%$ \\
\hline
\end{tabular}

Source: Data processed

The accuracy rate Bhandari's z-score model is $85,09 \%[(94,44 \%+75,73 \%) / 2]$ of 215 companies that have been classified correctly in the same group with the data originally.

\section{Conclusion}

This research aimed to know whether the predictor variables on Bhandari's z-score model having discriminating power which in each of the group has significant difference. The result of this study showed predictor variable that gave discriminating power which stood of quality of earning (EAQ), operating cash flow divided by current liabilities (OCFCL), operating cash flow margin (OCFM), and operating cash flow return on total assets (OCFA) in distinguishing the healthy and unhealthy company significantly. Based on the maximum value of the Mahalanobis distance indicates that the variable quality of earnings (EAQ) on the Bhandari's z-score model most significant in distinguishing unhealthy or healthy company.

Table Wilks' Lambda indicate that the significance level $(0.000<0.05)$ in all four predictor variables that have discriminating power it means that all four predictor variables are really significant or significantly different in each group. Based on the classification results show that accuracy rate of the Bhandari's z-score model to predict unhealthy or healthy company is $86.20 \%$, while calculations performed accuracy rate of Bhandari's zscore model using Excel to predict corporate bankruptcy is $85.09 \%$.

This study has limitations including sample used only manufacturing company which is composed of unhealthy and healthy companies in 2012-2014 are listed in the Indonesia Stock Exchange, so that in the 
future research can increase the sample as a bankrupt company, or add other aspects in the study as the economic situation is happening or others aspect that can affect the rate of bankruptcy of the company.

\section{References}

Afriyeni, E. (2012). Model Prediksi Financial Distress Perusahaan. Polibisnis Vol. 4 No. 5, 1-10.

Almilia, L. S. (2006). Prediksi Kondisi Financial Distress Perusahaan Go-Public dengan Menggunakan Analisis Multinominal Logit. Jurnal Ekonomi dan Bisnis, 1-26.

Altman, E. I. (1968). Financial Ratio, Discriminant Analysis and The Prediction of Corporate Bankruptcy. The Journal of Finance Vol. XXIII No.4, 589-609.

Altman, E. I., Danovi, A., \& Falini, A. (2008). Z-score Models' Application to Italian Companies Subject to Extraordinary Administration. Economics \& Management, Universita Degli Italy.

Beaver, W. H. (1966). Financial Ratio as Predictors of Failure. Empirical Research in Acoounting, 71111.

Bhandari, S. B., \& Iyer, R. (2013). Predicting Business Failure Using Cash Flow Statement Based Measures. Managerial Finance Vol. 39 No. 7, 667-676.

Brahmana, R. K. (2007). Identifying Financial Distress Condition in Indonesia Manufacture Industry. Birmingham Business School, University of Birmingham United Kingdom.

Campa, D., \& Minano, M.-d.-M. (2015). The Impact of SME'a Pre-bankruptcy Financial Distress on Earnings Management Tools. International Review of Financial Analysis, 1-13.

Eliu, V. (2014). Pengaruh Financial Leverage dan Firm Growth Terhadap Financial Distress. Finesta Vol. 2 No.2, 6-11.

Geng, R., Bose, I., \& Chen, X. (2015). Prediction of Financial Distress: An Empirical Study of Listed Chinese Companies Using Data Mining.
European Journal of Operational Research, 236-247.

Ghozali, I. (2012). Aplikasi Analisis Multivariate dengan Program IBM SPSS 20, edisi 6. Semarang: Badan Penerbit Universitas Diponegoro.

Gudono. (2012). Analisis Data Multivariat. Yogyakarta: BFEE-YOGYAKARTA, cetakan Pertama.

Gunawan, F. F., Rudiawarni, F. A., \& Sutanto, A. C. (2014). Hubungan Antara Financial Distress dengan Earnings Management pada Badan Usaha Sektor Manufaktur yang Terdaftar di BEI Periode 2010-2012. Jurnal Ilmiah Mahasiswa Universitas Surabaya Vol. 3 No. 1, 1-18.

Habib, A., Bhuiyan, M. B., \& Islam, A. (2013). Financial Distress, Earnings Management and Market Pricing of Accruals During The Global Financial Crisis. Managerial Finance Vol. 39 No. 2, 155-180.

Harahap, S. S. (2015). Analisis Kritis atas Laporan Keuangan. Jakarta: PT. Raja Grafindo Persada, Cetakan ke-12.

Hidayat, M. A., \& Meiranto, W. (2014). Prediksi Financial Distress Perusahaan Manufaktur di Indonesia. Diponegoro Journal of Accounting Vol. 3 No. 3, 1-11.

Hosen, M. N., \& Nada, S. (2013). Pengukuran Tingkat Kesehatan dan Gejala Financial Distress Bank Umum Syariah. Jurnal Economia Vol. 9 No. 2, 215-226.

Jensen, M. C., \& Meckling, W. H. (1976). Theory of the Firm: Managerial Behavior, Agency Costs and Ownership Structure. Journal of Financial Economics Vol. 3 No. 4, 305-360.

Mas'ud, I., \& Srengga, R. M. (2013). Analisis Rasio Keuangan untuk Memprediksi Kondisi Financial Distress Perusahaan Manufaktur yang Terdaftar di Bursa Efek Indonesia. Jurnal Akuntansi Universitas Jember, 139-154.

Nanayakkara, K., \& Azeez, A. (2015). Predicting Corporate Financial Distress in Sri Lanka: An Extension to Z-Score Model. International Journal of Business and Social Research Vol. 05 No. 03, 41-56. 
Prabowo, P. H. (2015). Analisis Kebangkrutan Perusahaan Berbasis Laporan Arus Kas Pada Perusahaan Sub Sektor Perdagangan Besar yang Terdaftar di Bursa Efek Indonesia. Jurnal Akuntansi dan Sistem Teknologi Informasi Vol. 11 No. 1, 1-8.

Prasad, K., \& Ravinder, G. (2012). A Camel Model Analysis of Nationalized Banks in India. International Journal of Trade and Commerce Vol. 1 No. 1, 23-33.

Salehi, M., \& Abedini, B. (2009). Financial Distress Prediction in Emerging Market: Empirical Evidences from Iran. Business Intelligence Journal Vol. 2 No. 2, 398-409.

Sarwono, J. (2015). Rumus-rumus Populer dalam SPSS 22 untuk Riset Skripsi. Yogyakarta: ANDI OFFSET edisi I.

Shamsudin, A., \& Kamaluddin, A. (2015). Impending Bankruptcy: Examining Cash Flow Pattern of Distress and Healty Firms. Procedia Economics and Finance, 766-774.

Sharma, D. S. (2001). The Role of Cash Flow Information in Predicting Corporate Failure: The State of the Literature. Managerial Finance Vol. 27 No. 4, 3-28.

Sulub, S. A. (2014). Testing the Predictive Power of Altman's Revised Z' Model: The Case of 10 Multinational Companies. Research Journal of Finance and Accounting Vol. 5 No. 21, 174-184. Suwardjono. (2014). Teori Akuntansi-Perekayasaan Pelaporan Keuangan Edisi Ketiga. Yogyakarta: BPFE-YOGYAKARTA, Cetakan Kedelapan. 